\title{
Compression Strength of Geopolymer Lightweight Concrete of Rice Husk Ask With Foam Agent
}

\author{
Kukuh Kurniawan D. $\mathrm{S}^{1}$, Teguh Yuono ${ }^{2}$ \\ \{kukuhkds@utp.ac.id ${ }^{1}$, yuonoteguh.ty@utp.ac.id $\left.{ }^{2}\right\}$ \\ Tunas Pembangunan University, Surakarta, Indonesia ${ }^{12}$
}

\begin{abstract}
Substitutes for concrete binders were introduced with the name geopolymer. Geopolymer is a concrete technology that utilizes polymerization reactions in the binding process. Rice husk ash is by-product material that has a high silica content $\left(\mathrm{SiO}_{2}\right)$. The purpose of this study is to determine the effect of using rice husk ash as pozzolanic on lightweight geopolymer concrete with foam agent to the compressive strength of concrete cubes. Mix design of lightweight geopolymer concrete using ratio of Sodium Silicate:Sodium Hydroxide is 2.5:1. Curing time of the concrete by heating in an oven for 24 hours at $80^{\circ} \mathrm{C}$. The study results obtained from testing the compressive strength of lightweight geopolymer concrete at 28 days, with comparison of rice husk ash and alkali activator 50\%:50\% resulted in the highest compressive strength of $1.87 \mathrm{MPa}$. Light concrete compressive strength with ash ratio of geopolymer rice and alkali activator, $60 \%: 40 \%$ and $70 \%: 30 \%$, is $1.46 \mathrm{MPa}$ and $1.36 \mathrm{MPa}$.
\end{abstract}

Keywords: geoplymer concrete, lightweight, rice husk ash, foam agent.

\section{Introduction}

Various types of concrete technology are continuously being developed, in order to obtain various advantages and concrete applications in special environments. Compared to other construction materials, concrete is very popular and has various advantages such as: low cost, easy to work, high strength, resistant to weather changes, etc. However, concrete has several weaknesses, including the one with very large specific gravity, so that the concrete has a very large dead load.

The specific gravity of the concrete is directly proportional to the strength of the concrete, the higher the specific gravity of the concrete, the higher the strength, and the lighter the concrete the smaller the strength. Concrete with a light weight type, can be used for non-structural construction materials. The use of lightweight concrete for walls (light brick) which has advantages over the use of walls with clay bricks. Lightweight concrete bricks have a higher strength than bricks, the specific gravity can be lighter. This lightweight concrete has a specific gravity of less than $1800 \mathrm{~kg} / \mathrm{m}^{3}$. To obtain lightweight concrete can be with several technologies, one of which is by inserting air into concrete or mortar. In the manufacture of concrete or mortar mix concrete will be added foam (foam agent), with the aim that the concrete mixture can expand.

Concrete technology without cement from limestone continues to be developed in various countries, including in Indonesia. One of these technologies is known as geopolymer. Geopolymer is a concrete technology that utilizes polymerization reactions in the binding

ICCSET 2018, October 25-26, Kudus, Indonesia

Copyright () 2018 EAI

DOI 10.4108/eai.24-10-2018.2280520 
process. The main composition of this geoplimer material is silica and alumina (alumino silica hydroxide). The silica material used is derived from inorganic materials that have high silica content.

Rice husk is a byproduct of rice processing, if it is burned to ash, it can produce material with a high silica content $\left(\mathrm{SiO}_{2}\right)$. The content of silica $\left(\mathrm{SiO}_{2}\right)$ in rice husk ash is $90-96 \%$, with high silica content can be used as a pozzolan for cement replacement.

The purpose of this study is to determine the effect of using rice husk ash as pozzolanic on lightweight geopolymer concrete with foam agent to compressive strength of concrete cubes.

\section{Literature Review}

\subsection{Lightweight Concrete}

Concrete is called lightweight, if it has a weight of less than $1800 \mathrm{~kg} / \mathrm{m}^{3}$. Two methods for making lightweight concrete, the first is forming using lightweight aggregates with a small specific gravity, called lightweight aggregate concrete. The second is to make a high pore in a mortar, which is to increase the air content into it.

In this study, to get lightweight concrete, by entering air by adding a foam (foaming agent). The addition of foaming agent can form hydrogen gas bubbles in a concrete mixture. Hydrogen gas contained in the concrete will be released and become pores in the concrete, so that the specific gravity of the concrete becomes lighter.

\subsection{Geopolymer Concrete}

Geopolymer concrete is a new material whose manufacturing process does not require the presence of portland cement as a binding material[1]. Binder material in geopolymer concrete is replaced with inorganic polymer material which has the main content of silica and alumina, the concrete binding reaction is a polymerization reaction.

In the polymerization reaction Aluminum $(\mathrm{Al})$ and Silica $(\mathrm{Si})$ have an important role in the polymerization bond because the reaction of aluminum and silica with alkaline will produce $\mathrm{AlO}_{4}$ and $\mathrm{SiO}_{4}[2]$.

In polymerization consists of two processes, namely, the dissolution process and then followed by a polycondensation process. The dissolution process will produce silicate monomer $\left(\mathrm{Si}(\mathrm{OH})_{4}\right)$ and aluminate ion $\left(\mathrm{Al}(\mathrm{OH})_{4}\right)$, and the polycondensation process will produce polymerization bonds -Si-O-Si and -Si-O-Al.

\subsection{Alkali Activator}

Alkaline activator solution that can produce optimum compressive strength is an alkali solution activator mixture between sodium hydroxide and sodium silicate[3]. Sodium hydroxide is an alkaline compound that is very reactive when mixed with water. The function of this compound is to react $\mathrm{Si}$ and $\mathrm{Al}$ to produce a strong polymerization bond.

Sodium hydroxide is an alkali compound that is very reactive when reacted with water. Sodium hydroxide is solid as powder. The function of sodium hydroxide is to react $\mathrm{Si}$ and $\mathrm{Al}$ to 
produce strong polymerization bonds. While sodium silicate serves to accelerate the polymerization reaction.

\subsection{Rice Husk Ash}

Rice husk has now been developed as a raw material to produce ash known in the world as Rice Husk Ash. Rice husk ash produced from burning rice husks at a temperature of $400^{\circ}-500^{\circ} \mathrm{C}$ will become amorphous silica and at temperatures greater than $1,000^{\circ} \mathrm{C}$ will be crystalline silica. The change of rice husk into silica ash after undergoing carbonization process is also a source of potent pozzolan as SCM (Supplementary Cementitious Material). Rice husk ash has very high pozzolanic activity so it is superior to other SCM such as fly ash, slag, and silica fume. Silica contained in the husk has a hydrated amorphous structure[4].

Tests carried out with XRF (X-Ray Fluorosence) on rice husk ash obtained the following compounds [5] :

Table 1. X-Ray Fluorosence Test of Rice Husk Ash.

\begin{tabular}{cc}
\hline Chemical Constituents & Precentage Composition $(\%)$ \\
\hline $\mathrm{SiO} 2$ & 96,400 \\
$\mathrm{~K} 2 \mathrm{O}$ & 2,720 \\
$\mathrm{CaO}$ & 0,639 \\
$\mathrm{MnO}$ & 0,073 \\
$\mathrm{Fe} 2 \mathrm{O} 3$ & 0,093 \\
$\mathrm{CuO}$ & 0,028 \\
$\mathrm{ZnO}$ & 0,042 \\
$\mathrm{Re} 2 \mathrm{O} 7$ & 0,021 \\
\hline
\end{tabular}

Rice husk ash from the by-product of burning bricks is heated at a surface temperature of about $277^{\circ} \mathrm{C}$ and the temperature in the pile of burning bricks is around $404^{\circ} \mathrm{C}$.

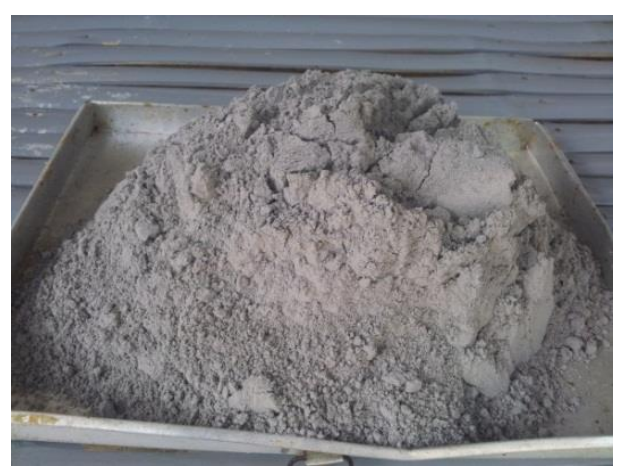

Fig. 1. Rice husk ash with fineness mess no. 100. 


\subsection{Foam Agent}

Foaming agent is a concentrated solution of surfactant material, and in its use must be dissolved with water. There are two basic methods that can be taken to produce gas/ air bubbles in concrete[6], as follows:

a. Gas concrete, made by entering a chemical reaction in the form of gas / air into a wet mortar, so that when mixed produces large amounts of gas / air bubbles. The most commonly used method is to add aluminum powder about $0.2 \%$ of the weight of cement to the mixture.

b. Foamed concrete, made by adding foam agent (liquid foam) into the mixture. Foam agent is one of the ingredients for foam making which is usually derived from protein hydrolyzed based ingredients. The foam agent forming material can be natural and artificial. Foam agent with natural ingredients in the form of protein has a density of $80 \mathrm{grams} /$ liter, while artificial ingredients in the form of synthetic have a density of 40 grams/liter. The function of this foam agent is to stabilize the air bubble during fast mixing.

\subsection{The Compressive Strength of Concrete}

The compressive strength of concrete is the ratio of the load to the cross-sectional area of the concrete. The concrete compressive strength is calculated based on equation 1 .

$$
K=P / A
$$

Where :

$\mathrm{K}=$ compressive strength of concrete cubes $\left(\left(\mathrm{kg} / \mathrm{cm}^{2}\right)\right.$

$\mathrm{P} \quad=$ load maximum $(\mathrm{kg})$

A $=$ cross section area $\left(\mathrm{cm}^{2}\right)$

\section{Methodology}

\subsection{Material}

The rice husk ash used came from by-product burning of bricks. which is refined and passed filter No. 100. Water is used from Laboratory of Building Materials, Civil Engineering Dept., Faculty of Engineering, Tunas Pembangunan University of Surakarta. Alkali activators used in the study are sodium silicate $(\mathrm{Na} 2 \mathrm{SiO} 3)$ and sodium hydroxide $(\mathrm{NaOH})$. This study uses foam agent type G-FOAM 1420.

\subsection{Mix Design}

Mix design of lightweight geopolymer concrete using 12 mol molarity and comparison of Sodium Silicate: Sodium Hydroxide is $2.5: 1$. Estimated concrete weight is $1600 \mathrm{~kg} / \mathrm{m}^{3}$. 
Comparison of the percentage of rice husk ash and alkali activator, is $70 \%: 30 \%, 60 \%: 40 \%$, $50 \%: 50 \%$.

Table. 2. Mix Design of Lightweight Geopolymer Concrete

\begin{tabular}{ccccccc}
\hline $\begin{array}{c}\text { Rice Husk } \\
\text { Ash:Alkali } \\
\text { Activator }\end{array}$ & $\begin{array}{c}\text { Sand } \\
(\mathrm{kg})\end{array}$ & $\begin{array}{c}\text { Water } \\
(\text { liter })\end{array}$ & $\begin{array}{c}\text { Rice Husk } \\
\text { Ash } \\
(\mathrm{kg})\end{array}$ & $\begin{array}{c}\text { Sodium } \\
\text { Silicate } \\
(\mathrm{kg})\end{array}$ & $\begin{array}{c}\text { Sodium } \\
\text { Hydroxide } \\
(\mathrm{kg})\end{array}$ & $\begin{array}{c}\text { Foam Agent } \\
(\mathrm{ml})\end{array}$ \\
\hline $70 \%: 30 \%$ & 880 & 252 & 327.6 & 100.3 & 40.1 & 600 \\
$60 \%: 40 \%$ & 880 & 252 & 280.8 & 133.7 & 53.5 & 600 \\
$50 \%: 50 \%$ & 880 & 252 & 234.0 & 167.1 & 66.9 & 600 \\
\hline
\end{tabular}

\section{Result and Discussion}

\subsection{Specific Gravity of Lightweight Geopolymer Concrete}

The results of the mix design of lightweight geopolymer concrete using foam agents obtained by concrete weight are as follows:

Table. 2. Specific Gravity of Lightweight Geopolymer Concrete.

\begin{tabular}{cccccc}
\hline \multicolumn{5}{c}{ Rice Husk Ash : Alkali Activator } \\
\hline \multicolumn{7}{c}{$50 \%: 50 \%$} & \multicolumn{2}{c}{$60 \%: 40 \%$} & $70 \%: 30 \%$ \\
\hline \multirow{2}{*}{$\begin{array}{c}\text { Weight } \\
(\mathrm{kg})\end{array}$} & $\begin{array}{c}\text { Specific } \\
\text { Gravity } \\
(\mathrm{kg} / \mathrm{m} 3)\end{array}$ & $\begin{array}{c}\text { Weight } \\
(\mathrm{kg})\end{array}$ & $\begin{array}{c}\text { Specific } \\
\text { Gravity } \\
(\mathrm{kg} / \mathrm{m} 3)\end{array}$ & $\begin{array}{c}\text { Weight } \\
(\mathrm{kg})\end{array}$ & $\begin{array}{c}\text { Specific } \\
\text { Gravity } \\
(\mathrm{kg} / \mathrm{m} 3)\end{array}$ \\
\hline 4.9 & 1452 & 4.45 & 1319 & 4.7 & 1393 \\
4.7 & 1393 & 4.5 & 1333 & 4.4 & 1304 \\
4.65 & 1378 & 4.4 & 1304 & 4.5 & 1333 \\
4.85 & 1437 & 4.55 & 1348 & 4.5 & 1333 \\
4.8 & 1422 & 4.45 & 1319 & 4.6 & 1363 \\
4.65 & 1378 & 4.45 & 1319 & 4.5 & 1333 \\
\hline
\end{tabular}

Measurements of lightweight geopolymer lightweight concrete were obtained by comparison with rice husk ash and alkali activator with a composition of 50\%: 50\%, 60\%: 40\% and 70\%: $30 \%$ in the category of lightweight concrete. The percentage of foam agent is 600 $\mathrm{ml} / \mathrm{m}^{3}$.

\subsection{Compressive Strength Test of Lightweight Geopolymer Concrete}

The compressive strength test of geopolymer lightweight concrete at 28 days was obtained as follows: 
Table. 3. Compressive Strength Test of Lightweight Geopolymer Concrete.

\begin{tabular}{|c|c|c|c|c|c|}
\hline $\begin{array}{c}\text { Rice Husk } \\
\text { Ash : Alkali } \\
\text { Activator }\end{array}$ & $\begin{array}{c}\text { cross } \\
\text { section area } \\
\left(\mathrm{cm}^{2}\right)\end{array}$ & $\begin{array}{l}\text { Maximum } \\
\text { Load } \\
(\mathrm{kg})\end{array}$ & $\begin{array}{c}\text { Compressive } \\
\text { Strength } \\
(\mathrm{kg} / \mathrm{cm} 2)\end{array}$ & $\begin{array}{l}\text { Compressive } \\
\text { Strength } \\
(\mathrm{MPa})\end{array}$ & $\begin{array}{l}\text { Average } \\
\text { compressive } \\
\text { strength } \\
\text { (MPa) }\end{array}$ \\
\hline \multirow{7}{*}{$50 \%: 50 \%$} & 224 & $5,098.50$ & 22.81 & 1.9 & \multirow{7}{*}{1.87} \\
\hline & 222 & $5,608.35$ & 25.26 & 2.1 & \\
\hline & 225 & $5,608.35$ & 24.93 & 2.1 & \\
\hline & 221 & $4,588.65$ & 20.81 & 1.7 & \\
\hline & 224 & $4,588.65$ & 20.53 & 1.7 & \\
\hline & 224 & $4,588.65$ & 20.53 & 1.7 & \\
\hline & 225 & $3,568.95$ & 15.86 & 1.3 & \\
\hline \multirow{4}{*}{$60 \%: 40 \%$} & 219 & $4,588.65$ & 20.95 & 1.7 & \multirow{5}{*}{1.46} \\
\hline & 221 & $4,078.80$ & 18.50 & 1.5 & \\
\hline & 222 & $3,568.95$ & 16.08 & 1.3 & \\
\hline & 225 & $3,568.95$ & 15.86 & 1.3 & \\
\hline \multirow{7}{*}{$70 \%: 30 \%$} & 224 & $4,078.80$ & 18.25 & 1.5 & \\
\hline & 219 & $4,078.80$ & 18.62 & 1.5 & \multirow{6}{*}{1.36} \\
\hline & 221 & $3,059.10$ & 13.87 & 1.2 & \\
\hline & 222 & $3,568.95$ & 16.08 & 1.3 & \\
\hline & 225 & $3,059.10$ & 13.60 & 1.1 & \\
\hline & 225 & $4,078.80$ & 18.13 & 1.5 & \\
\hline & 225 & $4,078.80$ & 18.13 & 1.5 & \\
\hline & 2.00 & & & & \\
\hline & 1.90 & & & & \\
\hline & 1.80 & & & & \\
\hline & है 1.70 & & & & \\
\hline & 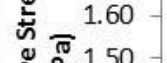 & & & & \\
\hline & $\bar{y} \Sigma_{1.40}$ & & & & \\
\hline & 1.30 & & & & \\
\hline & రิ 1.20 & & & & \\
\hline & 1.10 & & & & \\
\hline & 1.00 & & & & \\
\hline & $50 \%$ & $0 \% \quad 60 \%$ & $0 \% \quad 70 \%: 3$ & & \\
\hline & \multicolumn{4}{|c|}{ Comparison of Rice Husk Ash and Alkali Activator } & \\
\hline
\end{tabular}

Fig. 4. Relationship of Comparison of Rice Husk Ash and Alkali Activator with Compressive Strenght of Geopolymer Lightweight Concrete. 
The results obtained from testing the compressive strength of lightweight geopolymer concrete at 28 days, a ratio of 50\%: $50 \%$ resulted in the highest compressive strength of $1.87 \mathrm{MPa}$. And lightweight geopolymer concrete with a ratio of $60 \%: 40 \%$ and $70 \%: 30 \%$ each has the highest average compressive strength of $1.46 \mathrm{MPa}$ and $1.36 \mathrm{MPa}$.

In lightweight geopolymer concrete with a ratio of 70\%: $30 \%$, it can be seen that on the inside of the test object (sand) is not homogeneous, it appears that the aggregate bond does not occur. Comparison of alkali activator and rice husk ash 70\%: 30\% is not ideal, because the amount of rice husk ash is many, so it does not react optimally.

\section{Conclusions}

The results of the study of lightweight concrete geopolymer of rice husk ash using foam agent obtained conclusions:

1. Geopolymer lightweight concrete of rice husk ash using foam agent, with the percentage of rice husk ash and alkali activator 50\%: 50\%, 60\%: $40 \%$ and 70\%: $30 \%$ can produce concrete specific gravity below $1800 \mathrm{~kg} / \mathrm{m} 3$.

2. Maximum concrete compressive strength was obtained in the ratio of rice husk ash and 50\%: $50 \%$ alkali activator at 28 days at $1.87 \mathrm{MPa}$.

3. Comparison of rice husk ash and alkali activator 70\%: $30 \%$ is not ideal, because the amount of rice husk ash is numerous, so it is not homogeneous.

\section{Acknowledgments}

This research was funded by the Ministry of Research, Technology and Higher Education of the Republic of Indonesia as part of the Beginner Lecturer Research Grant. In addition, the authors acknowledge the technical support provided by LLDIKTI region VI and Tunas Pembangunan University of Surkarta.

\section{References}

[1] Chareerat T, Pimraksa K, P. Chindaprasirt, A. Maegawa, and S. Hatanaka, "Composition And Microstructure Of Fly Ash Geopolimer Containing Rice Husk Ash," in Technology and Innovation for Sustainable Development Conference, 2008.

[2] J. Davidovits, "Properties of Geopolymer Cements." pp. 131-149, 1994.

[3] Palomo A, Grutzeck M.W, and Blanco M.T, "Alkali-activated fly ashes: A cement for the future." Cement and Concrete Research, 29(8), 1323-1329. https://doi.org/10.1016/S0008-8846(98)00243-9, 1999.

[4] Harsono H., "Making Amorphous Silica from Rice Husk Waste,” J. Ilmu Dasar, pp. 98-103, 2002.

[5] Ilmiah R, "The Effect of Rice Husk Ash Addition as Pozzolan on Geopolymer Binder Using Alkali Activator of Sodium Silicate (Na2SiO3) and Sodium Hydroxide (NaOH).” 2017.

[6] Neville A.M and Brooks J.J, Concrete Technology 2nd Edition. New York: Longman Group UK Limited 1987., 2010. 